\title{
The Development of 'JEGER' Application Using Android Platform as History Learning Media and Model
}

\author{
https://doi.org/10.3991/ijet.v15i07.11649 \\ Wahyu Djoko Sulistyo ( $\left.{ }^{凶}\right)$, Moch. Nurfahrul Lukmanul K, Bayu Kurniawan \\ Universitas Negeri Malang, Malang, Indonesia \\ Wahyu.djoko.fis@um.ac.id
}

\begin{abstract}
This study aims to describe the development of the 'JEGER' application using android platform to develop a history learning media and model based on historical potential of General Soedirman's guerrilla in Pacitan, Indonesia. This development used three main steps adopted from Borg and Gall's model. The development scheme of the application takes a place as a media and model in history learning. The draft or prototype was validated by experts of learning material and media. The revised results of the validator's suggestion are tested to examine the effectiveness and feasibility. The average evaluation of the five assessment components showed an average of $92 \%$. It means that the application of "JEGER" is very effective and feasible as an innovative and creative media and model for historical learning.
\end{abstract}

Keywords-Application, 'JEGER', Guerrilla, General Sudirman, Pacitan

\section{Introduction}

The order of globalization has been stirred up recently by the shocks in the industrial revolution 4.0. This is not only a mere figment, but also a kind of affirmation of demarcation that the international community enter a new order. Since 2011, we have been in Industrial Revolution 4.0 marked by increased connectivity, interaction and boundaries between people, machines and other resources that are increasingly converging through information and communication technology. Airlangga Hartarto said at the Roadmap Implementation program of Industry revolution 4.0 in Jakarta [1]. An order that changes the old order (conventional) to new (modern) is characterized by the use of internet-based technology. But there is one thing that is clear: the world must respond to these changes in an integrated and comprehensive manner by involving all global political stakeholders, ranging from the public and private sectors to academics, and of course civil society[2, p. 0], [3]. It is no longer a complex set of components, but it is very simple that only by operating a smartphone is a wide range of coverage possible in a short amount of time.

Seeing a very potential infrastructure as an answer to a new order that is quickly felt by all people of the world in various aspects. One aspect that researchers try to examine is concerned with education. As one vehicle for the inculcation of values and knowledge for modern humans, education places an important role in the formation 
of humans needed by the times [2], [4]. A new learning model is needed or at least packaged with technology that is adapted to contemporary tastes to be done effectively for the subject of learning[5]-[7]. So that in this case, a breakthrough idea arises to develop a media and role model of learning in a unity that is identical to the current human style, that is framed with effective technology that is effective, practical and close to the needs of the main human life today [8]-[10]. One of the packages used as a form of innovation renewal here is to use an application that is operated with a smartphone or cell phone. Its use as a learning solution starts to become an appropriate choice[11]-[13]. Technology and mobile and web applications provide new possibilities for adding learning activities [14], [15].

To meet the needs of the times and answer challenges, the model is packaged in an Android application. Android is an operating system for mobile devices or Linuxbased mobile devices which includes an operating system, middleware, and applications[16]. Android provides an open platform for developers to create their applications [17]-[20]. In its future will be equipped with various interesting and interactive information features in addition to the steps of learning that become the main substance[21]-[23]. Some of the features presentations include brief material on guerrilla sites in terms of geographical and historical aspects, photo and video media that are representative and are equipped with "maps" as instructions to visit the site. As one of the local wealth that is used as a basis for the model and packaged in an application will be effective in its use[24], [25].

Utilization of local potential becomes interesting by looking at the contours of the area used as a guerrilla route of the General and his army is not a flat and easily accessible road but up and down the hill, breaking through the forest so that it gives new inspiration in outdoor learning activities in the model in this application[26], [27]. What is certain is that the natural field conditions are a relevant source of learning. Because the site used as the basis for the development of the model is a guerrilla site so that it is more interesting that the application that packs the model is called " JEGER " which is an acronym for Guerrilla Trail. The assumptions of researchers with the naming of the original, simple and interesting can increasingly arouse interest and motivation for anyone to install and learn following the features available in the application. Because it is hoped that this product can be used by all people in the school for students or anyone who wants to learn directly from the media or by visiting General Soedirman's guerrilla sites in Pacitan.

\section{$2 \quad$ Method}

This research uses the Research and Development (R\&D) method. This research is aimed at producing a product in the form of 'JEGER' with the use of local historical potential in Pacitan Regency, East Java. Therefore, the location that is used as the source of administrative data in the field is Kab. Pacitan Content material content from the application developed in this study is a site in the form of shelter and monument of General Soedirman in Pacitan. R\&D is a method to produce a product while testing the effectiveness of the products produced[28]-[30]. The results 
obtained by $R \& D$ research in education can be in the form of hardware such as books, modules, and other learning aids, as well as software such as learning models[31]. The general procedure of this research is grouped into three major group stages as follows:

1) Preliminary study

2) Model development

3) Model testing

Three steps that need to be done to obtain a valid, practical and efficient learning application, are described in the steps below:

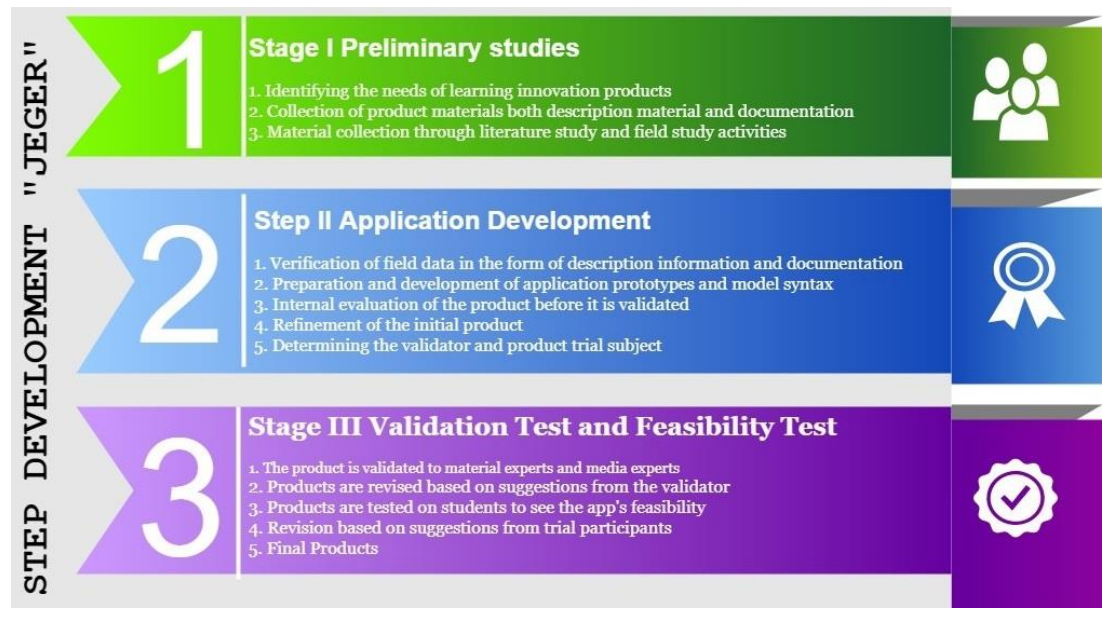

Fig. 1. Steps for JEGER application development

\section{Result and Discussion}

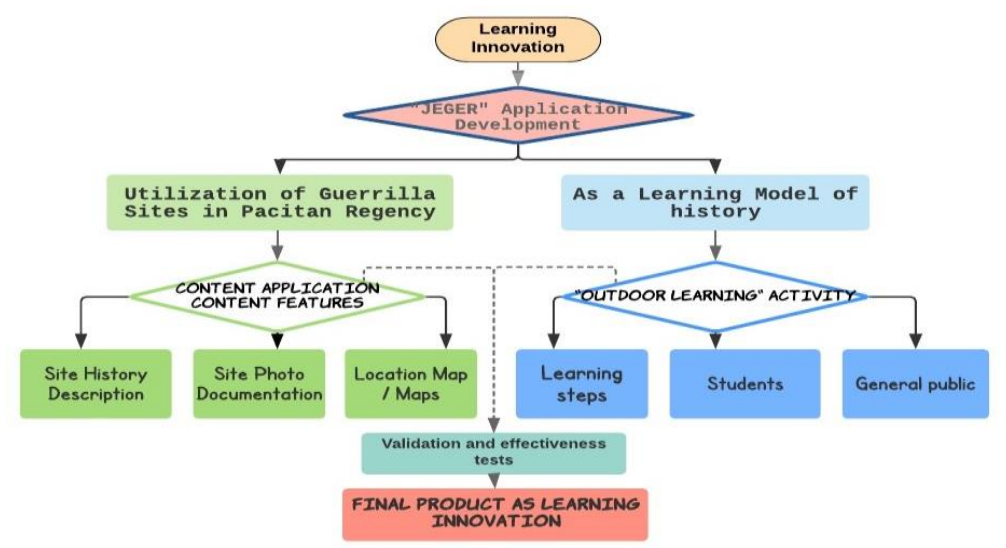

Fig. 2. "JEGER" Application Scheme as a Learning Innovation 


\subsection{Development scheme}

The times that are in line with technological advances and have an impact on the world of education also encourage the birth of innovative learning[32], [33]. Learning history is also encouraged to be able to innovate themselves both in terms of media, strategy, and models. Therefore, in this case, the application product was developed. Application Development 'JEGER' as a media and learning model of history is one of the innovations in learning, especially history. A further scheme of development is outlined in Figure 2 above.

To break new ground in a new paradigm of learning that fits the needs of the $21 \mathrm{st}$ century, an application called "JEGER" was developed. The name is an acronym for the 'Guerrilla Trail', which is meant here is the guerrilla trail of General Soedirman in Pacitan. He is a historical figure who played an important role in maintaining Indonesia's independence [34], [35], but studies of his struggle especially in a district called Pacitan are still very rare, what else is packaged in a modern way. Therefore in this development scheme, an Android-based application was prepared to contain the historical information of the guerrilla trail of the warrior. The android application was chosen for this product because based on a survey of needs analysis regarding the media and learning model $88 \%$ of respondents wanted this form, assuming practicality, effectiveness and following the child's taste in learning today.

This application can act as a medium and model of history learning. Following the scheme described in the chart above that as a medium of learning presents adequate information about the guerrilla trail. Covering in this media are features for a historical description of the site, photos or documentation of the site for the current conditions, and supporting videos about the condition of the guerrilla site. As a learning model application "JEGER " is equipped with a learning syntax that adopts an outdoor learning model. Utilization of guerrilla sites as a source of learning through direct experience[36], [37]. One of the features in this application is maps that can be accessed online to provide instructions for learners (students, students, and the general public) to visit guerrilla sites. The display on the main screen of the application is also a picture of the Pacitan Regency landscape.

\subsection{Validation results}

Following the step of development in the research method after the draft is well structured following a predetermined scheme, an expert assessment is carried out. The experts here are those who have the ability by the specifications of professionalism/expertise. For validators regarding this application is divided into two, namely experts for the material and experts for learning media. Material experts evaluate the substance of the historical material presented in this application, namely regarding the footsteps of General Soedirman's guerrilla in Pacitan. The expert who is a validator for the material is Arif Subekti, M.A, his study of the theme of political history is very appropriate to assess the material in this application. As for media experts, it looks at the completeness of the learning media elements and their use. For media experts who are following their expertise, Ulfatun Nafi'ah, M.Pd, the 
specifications of the study so far regarding the history of learning media, so it is very relevant to be a validator. Before it is submitted to the validator, the product is evaluated internally by the team so that it becomes a product of learning innovation according to the criteria with the display as below:
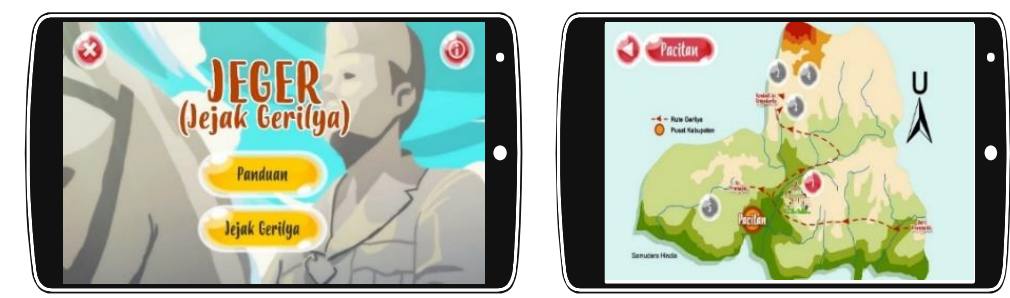

Fig. 3. Application Display p. Main is accessed via smartphone (Researcher Doc, 2019)

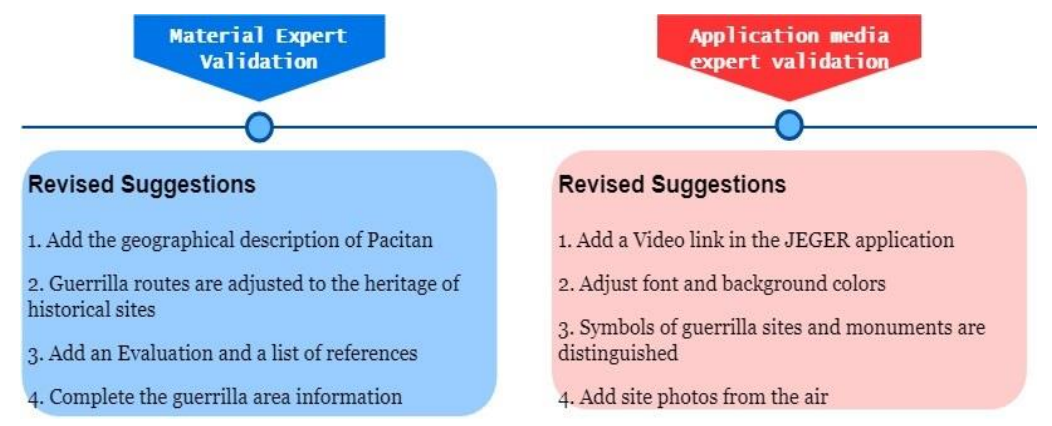

Fig. 4. Expert Validation Results (Research Data, 2019)

The results of validation both for material content and media elements get a decision that the material in this application is following historical data that can be accounted for. As for the effectiveness of the application " JEGER " as a medium, the elements have been fulfilled and are relevant for further feasibility testing. The results of the decision of the validator stated if this application is suitable for use as a medium and learning history with some notes to be revised before being tested. There are 4 notes for material improvement both substantively and informative and 4 notes for completing media elements. Note the suggested revisions of the validators are illustrated in the table below:

Note the suggestions for improvement from the validator that became the basis for the development team to make revisions to the product. The results of the product revision based on the researcher's suggestion generated an application view like the Screenshot image below: 

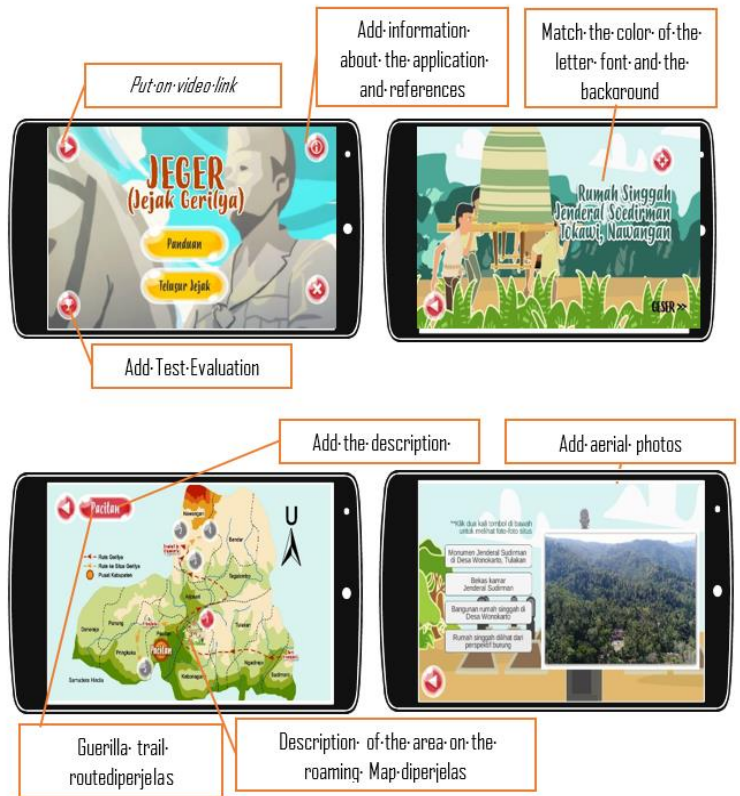

Fig. 5. Product revision display

\subsection{Product trial}

After repairs for all records of the validator are completed, a trial is carried out to determine the feasibility of the product. For the subjects of the trial activity, 100 sample participants were chosen to consist of students, students, teachers, and the general public. Sample selection is based on the purposive sample method with a random sampling technique [29]. The choice of place objects in two schools and campuses is due to the research team as instructors and supervisors of the institution. The following is the composition of the number of subjects:

Table 1. Trial Participant Data

\begin{tabular}{|c|c|c|c|}
\hline Students & College Students & Teacher and Lecturer & Public \\
\hline 50 & 37 & 8 & 5 \\
\hline
\end{tabular}

The highest number is the composition of students and students. For students from MA Bilingual Kota Batu and SMK N 2 Singosari, while students come from the history department of State University of Malang. In this trial phase the application is shared and installed on the participant's android, to further operate and access all information contained in the " JEGER" application. After that the participants were given an assessment questionnaire to provide an evaluation of the feasibility of the application both as a medium and a learning model[38]. 

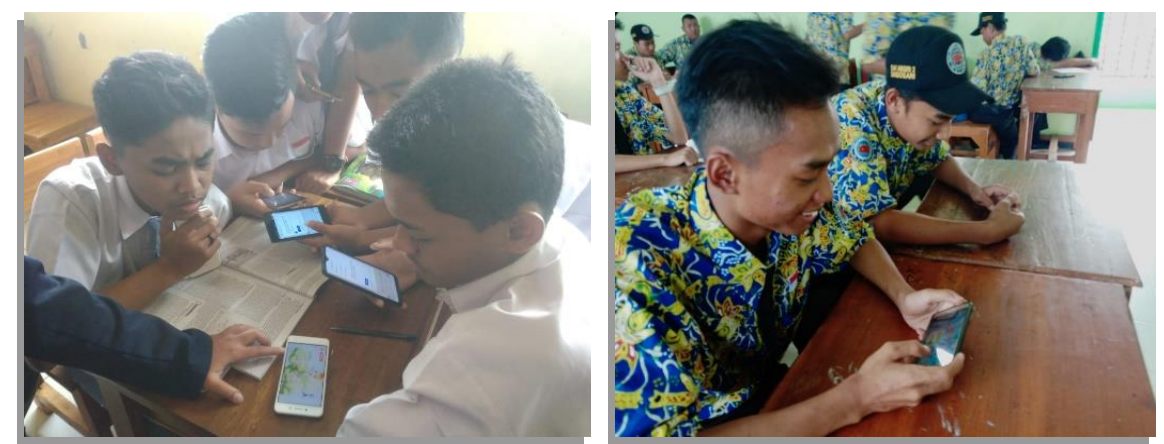

Fig. 6. JEGER application trial activities as a history learning media (Research Data, 2019)

In the evaluation questionnaire consists of five main components in the assessment.

a. For aspects of using the application 'JEGER' as media and models, the second component

b. Regarding the ease of accessing the application 'JEGER'.

c. Regarding the completeness of General Soedirman's guerrilla history information in Pacitan in the 'JEGER' application.

d. Regarding the appearance of an attractive and innovative application, and the last for the fifth component

e. The completeness of the supporting media features of learning contained in the application "JEGER",

From the results of the evaluation provided by the trial participants, the data described in the diagram below are given: 


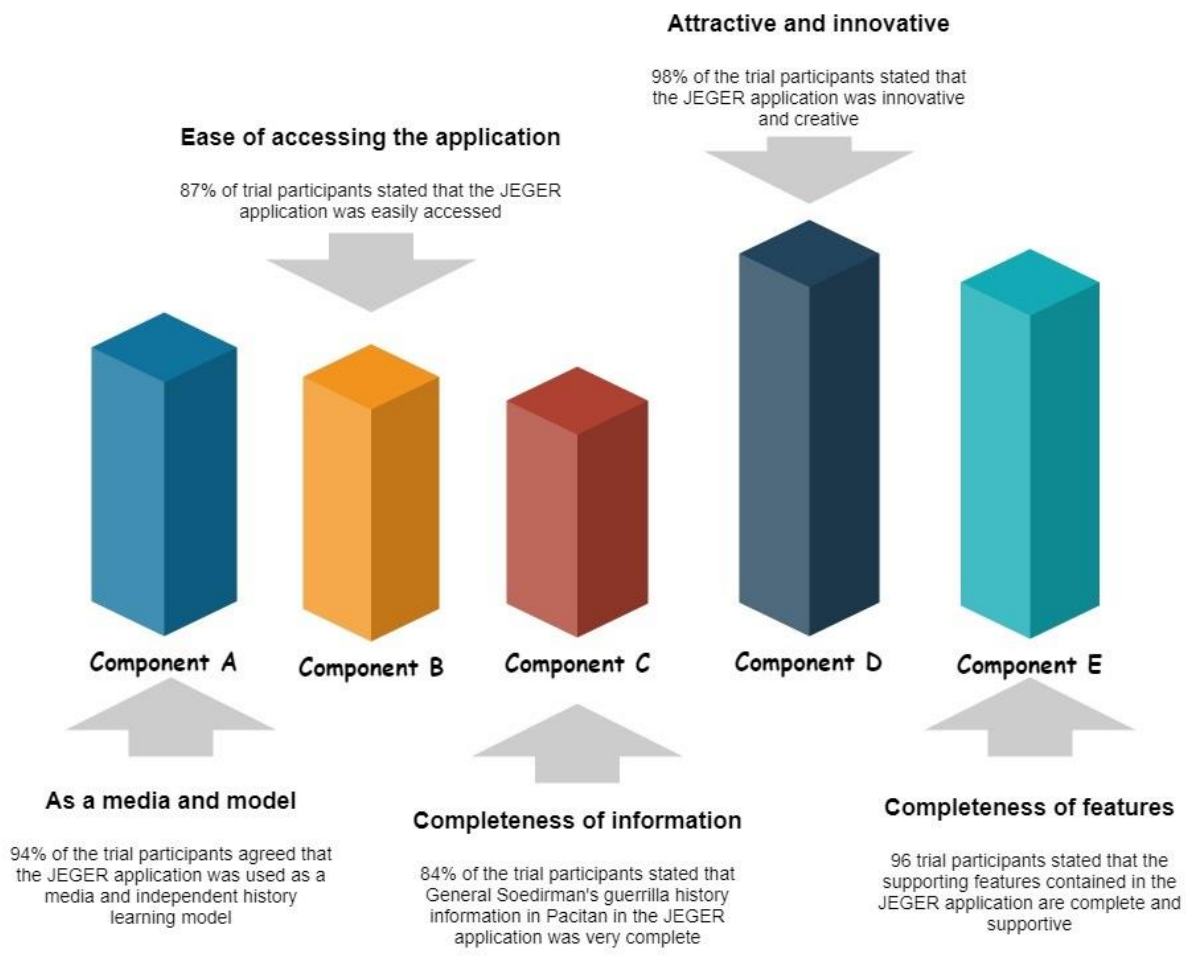

Fig. 7. Diagram of recapitulation of trial results (Research Data, 2019)

From the data in the diagram above it can be narrated that:

a. It reaches $94 \%$ of the test participants agree that the application " JEGER " can be used both as a medium and as a model in learning history. In this component, the maximum evaluation results are obtained because in general, it assesses the completeness of the learning syntax after operating this application. The operation of site roaming by guerrilla routes that the next site can be accessed after the site was previously accessed gives an illustration of the implementation of a series of learning system models.

b. $87 \%$ stated that the application "JEGER" is very easy to access and operate via the android participant. Achievement of the assessment is not as maximum as the other components because some trial participants experienced problems when the process of installing the application with their Android specifications, although in the end all can install and operate annum quite affect the results of the final assessment of the operation of the application "JEGER". The third component.

c. $84 \%$ of the trial participants stated that the presentation of information about General Soedirman's guerrilla network in Pacitan which was packaged in the "JEGER " application was very complete and informative. This component is 
also the same as the previous component, which is not as maximum as other components. This is because some of the trial participants did not first read the instructions for use and immediately chose the browse button, so they could not enjoy the completeness of the information. Besides, the information presented in this application following the initial design scheme is only the main information given the limited space in the application.

d. $98 \%$ of the trial participants stated that in appearance and design for the application " JEGER " was very interesting and innovative in the packaging of the android application. Maximum results are achieved through the assessment of this component because the appearance of the design is following the initial design and based on the results of the revision of the validator's suggestion is designed as attractive as possible. The choice of colors, fonts, and layout is adjusted to the style and tastes of today's children. This is the basis for the assessment so that the results achieved are optimal.

e. Of the trial participants who gave a $96 \%$ rating stated that the features of the completeness of the media contained in the application 'JEGER' were very complete and supportive. As with the previous component, this component also gets maximum results. The complete presentation of media support features displayed on the home page provides various alternative options for users to access.

Based on the achievement of the evaluation results on the appropriateness of the 'JEGER' application as a media and historical learning model consisting of the five assessment components above, it can be concluded that this application is feasible and effective. This conclusion is obtained based on the range of average percentages determined through the Likert scale[39]. as illustrated below:

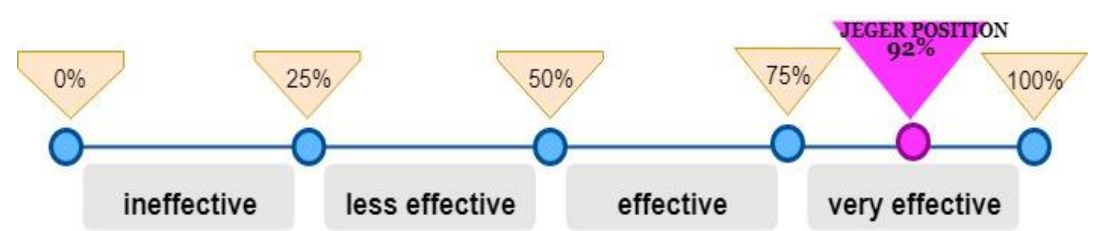

Fig. 8. Determining the position of the percentage of trial results in a Likert scale (Research Data, 2019)

Based on the results of the average value of the five assessment components, the results obtained at the point of $92 \%$. This means that following the position of the line drawing above the application " JEGER " in the last quarter area (4) so that it falls into the category of very feasible to be used as an innovative media and learning model of history and encourages learning independence. By the objectives of the research and development set out in the initial scheme. Affirming that learning innovation that is realized with Jeger application products can be an alternative solution in responding to the challenges of the times for learning history. 


\section{Conclusion}

The development of the 'JEGER' application based on an android application with the use of General Soedirman's guerrilla site in Pacitan Regency is one form of Learning Innovation especially History. During this time it is still rarely developed an application that covers peranya both as a media and a model. Therefore this application is arranged according to the level of learning innovation needs. Utilization of local potential is an attraction itself considering the history of learning so far has focused on national studies. The development method adopted in this study was simplified into three main steps. The first preliminary study, the second stage is development and the last stage is the test of effectiveness. In accordance with the learning innovation design scheme in the form of the 'JEGER' application, a product is ready to be validated. The result is some revised notes for product improvement. After the final phase of the revision is a trial to determine the level of effectiveness and feasibility of the application. The results obtained at this stage are 'very effective'. With this result it can be concluded that the application 'JEGER' is very feasible to be used as a creative and innovative media and learning model of history, in accordance with the changing times and able to be one of the alternative solutions to the challenges of historical learning so far towards the progress of the times. Overall, this development is feasible and easy to use. But, the contain is not cover the extend learning materials such as videos of historical site, a wide range of scope area, a simpler performance of the applicatiom, and other related materials. These additional materials could be a future potential topic for future research.

\section{$5 \quad$ References}

[1] Kemenperin.go.id, "Kemenperin: Making Indonesia 4.0: Strategi RI Masuki Revolusi Industri Ke-4,” 2019. [Online]. Available: https://kemenperin.go.id/artikel/18967/Making-Indonesia-4.0:-Strategi-RI-

Masuki-Revolusi-Industri-Ke-4. [Accessed:04-Sep-2019].https://doi.org/10.3 $1219 / \mathrm{osf} . \mathrm{io} / \mathrm{c} 3 \mathrm{vbj}$

[2] . Benešová and J. Tupa, "Requirements for education and qualification of people in Industry 4.0," Procedia Manufacturing, vol. 11, pp. 2195-2202, 2017. https://doi.org/10.1016/j.promfg.2017.07.366

[3] R. R. Tjandrawinata, "Industri 4.0: Revolusi industri abad ini dan pengaruhnya pada bidang kesehatan dan bioteknologi," Jurnal Medicinus, vol. 29, no. 1, 2016.

[4] V. Puncreobutr, "Education 4.0: new challenge of learning," St. Theresa Journal of Humanities and Social Sciences, vol. 2, no. 2, 2016.

[5] M. M. Grant, "Getting a grip on project-based learning: Theory, cases and recommendations," Meridian: A middle school computer technologies journal, vol. 5, no. 1, p. 83, 2002.

[6] M. M. Grant, "Difficulties in defining mobile learning: analysis, design characteristics, and implications," Education Tech Research Dev, vol. 67, no. 2, pp. 361-388, Apr. 2019. https://doi.org/10.1007/s11423-018-09641-4 
[7] S. Papadakis, M. Kalogiannakis, and N. Zaranis, "Designing and creating an educational app rubric for preschool teachers," Education and Information Technologies, vol. 22, no. 6, pp. 3147-3165, 2017. https://doi.org/10.10 07/s10639-017-9579-0

[8] Y.-C. Hsu et al., "Research Trends in Technology-based Learning from 2000 to 2009: A content Analysis of Publications in Selected Journals," Journal of Educational Technology \& Society, vol. 15, no. 2, pp. 354-370, 2012.

[9] R. S. Ascough, "Designing for online distance education: Putting pedagogy before technology," Teaching theology \& religion, vol. 5, no. 1, pp. 17-29, 2002. https://doi.org/10.1111/1467-9647.00114

[10] A. Maseleno et al., "Understanding Modern Learning Environment (MLE) in Big Data Era," Int. J. Emerg. Technol. Learn., vol. 13, no. 05, p. 71, Apr. 2018. https://doi.org/10.3991/ijet.v13i05.8042

[11] M. K. Foti and J. Mendez, "Mobile learning: how students use mobile devices to support learning," Journal of Literacy and Technology, vol. 15, no. 3, pp. 58-78, 2014.

[12] A. König and D. Bernsen, "Mobile Learning in History Education," Journal of Educational Media, Memory \& Society, vol. 6, no. 1, pp. 107-123, 2014.

[13] S. Papadakis and M. Kalogiannakis, "Mobile educational applications for children: what educators and parents need to know," Int. J. Mobile Learning and Organisation, vol. 11, no. 3, 2017. https://doi.org/10.1504/ijmlo.2017.085338

[14] B. Vogel, A. Kurti, M. Milrad, E. Johansson, and M. Müller, "Mobile inquiry learning in Sweden: Development insights on interoperability, extensibility and sustainability of the LETS GO software system," Journal of Educational Technology \& Society, vol. 17, no. 2, pp. 43-57, 2014.

[15] S. Papadakis, M. Kalogiannakis, and N. Zaranis, "Educational apps from the Android Google Play for Greek preschoolers: A systematic review," Computers \& Education, vol. 116, no. 1, pp. 139-160, 2018. https://doi.org/10.1016/j. compedu.2017.09.007

[16] G. Milette and A. Stroud, Professional Android sensor programming. John Wiley \& Sons, 2012.

[17] A. Ahmar and A. Rahman, "Development of teaching material using an Android," Global Journal of Engineering Education, vol. 19, no. 1, 2017. https://doi.org/10.26858/gjeev19i1y2017p7376

[18] H. Fahri and K. Samsudin, "Mobile Learning Environment System (MLES): The Case of Android-based Learning Application on Undergraduates' Learning," IJACSA, vol. 3, no. 3, 2012.

[19] S. Sari, R. Anjani, I. Farida, and M. A. Ramdhani, "Using android-based educational game for learning colloid material," in Journal of Physics: Conference Series, 2017, vol. 895, p. 012012.

[20] M. Kalogiannakis and S. Papadakis, "An evaluation of Greek educational Android apps for preschoolers," in proceedings of the 12th Conference of the European Science Education Research Association (ESERA), Research, Practice and Collaboration in Science Education, Dublin City University and the University of Limerick, Dublin, Ireland, 2017, pp. 21-25. https://doi.org/10.1456 9/ijacsa.2012.030311 
[21] B. C. Buckley, "Interactive multimedia and model-based learning in biology," International journal of science education, vol. 22, no. 9, pp. 895-935, 2000. https://doi.org/10.1088/1742-6596/895/1/012012

[22] R. E. Mayer, G. T. Dow, and S. Mayer, "Multimedia learning in an interactive self-explaining environment: What works in the design of agent-based microworlds?," Journal of educational psychology, vol. 95, no. 4, p. 806, 2003. https://doi.org/10.1037/0022-0663.95.4.806

[23] H. Huang, "Design and Implementation of a College English Listening Learning System Based on Android Platform," Int. J. Emerg. Technol. Learn., vol. 13, no. 07, p. 43, Jun. 2018. https://doi.org/10.3991/ijet.v13i07.8779

[24] Y.-T. Lin, Y.-M. Tseng, Y.-S. Lee, T.-C. Wang, S.-I. Tsai, and Y.-J. Yi, "Development of a SoLoMo Game-Based Application for Supporting Local Cultural Learning in Taiwan," Journal of Educational Technology \& Society, vol. 21, no. 4, pp. 115-128, 2018.

[25] W. D. Sulistyo, U. Nafi'ah, and I. Idris, "The Development of E-PAS Based on Massive Open Online Courses (MOOC) on Local History Materials," International Journal of Emerging Technologies in Learning (iJET), vol. 14, no. 09, pp. 119-129, May 2019. https://doi.org/10.3991/ijet.v14i09.10143

[26] J. Sayono, L. Ayundasari, W. D. Sulistyo, and R. Ridhoi, "Utilization of Syphon Metro Kepanjen as Outdoor Learning Site for History Students," in 1st International Conference on Social Knowledge Sciences and Education (ICSKSE 2018), 2019. https://doi.org/10.2991/icskse-18.2019.14

[27] W. D. Sulistyo, "Learning Activities from Learning Resources: Pemanfaatan dan Pemaknaan Situs Sejarah Kawasan Alun-Alun Merdeka Kota Malang," Jurnal Pendidikan Sejarah Indonesia, vol. 2, no. 1, pp. 49-63, 2019. https://doi.org/10.17977/um033v2i12019p049

[28] M. D. Gall and W. R. Borg, Educational Research. A Guide for Preparing a Thesis or Dissertation Proposal in Education. ERIC, 1989.

[29] Sugiyono, Metode penelitian pendidikan :(pendekatan kuantitatif, kualitatif dan $R \& D)$. Alfabeta, 2008.

[30] M. D. Gall, W. R. Borg, and J. P. Gall, Educational research: An introduction. Longman Publishing, 1996.

[31] N. S. Sukmadinata, Metode Penelitian Pendidikan, 12th ed. Bandung: PT Remaja Rosdakarya, 2017.

[32] A. Drejer, "Innovation and learning," International Journal of Innovation and Learning, vol. 1, no. 1, pp. 9-23, 2003.

[33] B. Kurniawan, I. Idris, A. Purnomo, A. Wiradimadja, and S. Sukamto, "Using Broadcasting Learning Design to Enhance Student's Experiential Skill," International Journal of Emerging Technologies in Learning (iJET), vol. 14, no. 16, pp. 172-180, Aug. 2019. https://doi.org/10.3991/ijet.v14i16.10652

[34] A. H. Nasution, Sekitar perang kemerdekaan Indonesia: Agresi militer belanda II, vol. 9. DISJARAH-AD, dan Penerbit Angkasa, 1991.

[35] T. B. Tempo, Soedirman Seorang Panglima, Seorang Martir. Kepustakaan Populer Gramedia, 2013.

[36] H. Bilton, Outdoor learning in the early years: Management and innovation. Routledge, 2010. 
[37] D. Eaton, "Cognitive and affective learning in outdoor education," $\mathrm{PhD}$ Thesis, National Library of Canada= Bibliothèque nationale du Canada, 2000.

[38] R. M. Grinnell Jr and Y. Unrau, Social work research and evaluation: Quantitative and qualitative approaches. Cengage Learning, 2005.

[39] I. E. Allen and C. A. Seaman, "Likert scales and data analyses," Quality progress, vol. 40, no. 7, pp. 64-65, 2007.

\section{Authors}

Wahyu Djoko Sulistyo is an Indonesian Historical Education, one of the lecturers in History Department, Faculty of Social Science, Universitas Negeri Malang. He is interested in educational history and learning innovation.

Moch. Nurfahrul L. K. is a lecturer in Faculty of Social Science, Universitas Negeri Malang, Indonesia. $\mathrm{He}$ is majoring in in learning media and related information technology in education.

Bayu Kurniawan is an Indonesian Historical Education, one of the lecturers in Faculty of Social Science, Universitas Negeri Malang, Indonesia. His research interest is education and learning innovation.

Article submitted 2019-09-11. Resubmitted 2019-11-12. Final acceptance 2019-11-12. Final version published as submitted by the authors. 